\title{
ANALYSIS CONCEPTION IN REVIEW OF ATTITUDES AND BEHAVIORS ON ENERGY ROLES IN LIFE BASED ON ENERGY LITERACY FRAMEWORK
}

\author{
Hana Puspitasari ${ }^{1}$, Dita Ardwiyanti ${ }^{1}$, Puji Rahayu ${ }^{1}$, Djumadi $^{2}$ \\ ${ }^{1}$ Science Education Study Program Student at Yogyakarta State University \\ ${ }^{2}$ Lecturer in Postgraduate Study Program of Natural Sciences in Yogyakarta State University
}

hanapuspitasari.3096@gmail.com

\begin{abstract}
Energy is the main resource that supports human life, lately developing alternative energy supporting the main source of energy is referred to as renewable energy. Renewable energy is a type of alternative energy that can be used as a companion to fossil energy. Awareness of energy use can be implemented to students through learning or energy literacy. Energy literacy can be developed in junior high school students by providing knowledge, attitudes, and positive behavior in the use of energy especially encouraging the role of energy in life. The measurement of energy literacy in this article aims to measure how students 'understanding of the role of energy through students' attitudes and behavior in saving energy as well as knowledge of alternative energy through relationships from 3 aspects. Through the energy literacy framework adapted from DeWaters measurements using an online questionnaire conducted on 183 students from several junior high schools in the area of Central Java. When viewed from the relationship of sex with the three aspects there is no relationship seen from the results of Chi Square. However, the relationship between aspects of saving energy and renewable energy and energy shows a relationship between the results of the questionnaire. So that the attitude of energy literacy shown by students is not affected by gender. However, the relationship between aspects of saving energy and renewable energy and energy shows a relationship between the results of the questionnaire. So that the attitude of energy literacy shown by students is not affected by gender. However, the relationship between aspects of saving energy and renewable energy and energy shows a relationship between the results of the questionnaire. So that the attitude of energy literacy shown by students is not affected by gender.
\end{abstract}

Keywords: energy, energy literacy, junior high school students

\section{PRELIMINARY}

Energy is one of the important discussions at this time and is the hottest conversation in the whole world. Issues regarding the depletion of resources and the impact caused by energy sources on the environment affect global and local conversation. The developed or existing energy influences a country's economy, in addition to choosing energy usage, it will also affect the level of a country's economy. The increasingly minimal fossil energy can be overcome by the use of ET (Renewable Energy) especially in Indonesia which has considerable potential in developing this ET by utilizing wind energy of 950 Megawatts, solar power by 11 Gigawatts, hydro power by 75 Gigawatts, biomass energy 32 Megawatts, biofues of 32 Megawatts, and geothermal energy of 29 Gigawatts. Utilization of many of these workers has not been maximized, based on records from the Ministry of Energy and Mineral Resources (ESDM) in 2015 the use of the largest energy sources still relies on fossil energy. Only 5\% of ET contributes to national energy utilization even though the growth of energy consumption jumps 
up to $8 \%$ per year. If this is left unchecked, the source of fossil energy will be depleted and the impacts will be more numerous (Ministry of Energy and Mineral Resources, 2016).

Energy literacy is interpreted by several experts such as according to Dewaters and Powers (2011) to define energy literacy as a domain of basic knowledge related to energy by adding understanding obtained from the results and use of energy in the environment how the energy is used and how the behavior in saving energy comes in three dimensions aspects namely knowledge, attitudes and behavior. According to Kalmi et al (2017), it leads to the awareness of users in utilizing energy in daily life and leads to understanding in the use of energy in the economic world. Brounen (2013), interpreting literacy in the narrow sense is more directed to the economic field in the scale of long-term use. According to Martins (2019), adopted from the understanding of the United States Department of Energy that energy literacy not only covers the attitude and role of energy in daily life also includes the skills to obtain information to answer and solve energy-related problems and to incorporate the aspects raised by DeWaters consisting of three aspects. So that energy literacy is not just about what the role of energy in daily life is how it is useful but the skills in getting information from problems around energy and how to respond and behave.

The Energy Literacy Association (2009) says that the resource that has the greatest potential to meet national energy limitations is the awareness of energy literacy. Literacy does not merely consist of knowledge, people have an awareness of energy literacy that has the characteristics of being aware and knowledgeable about the importance of energy to energy, understanding the use of energy in daily life, the impact caused if it is not efficient in the use of energy, and the needs in energy conservation and development of alternative or renewable energy sources (Barrow \& Morrisey, 1989). When energy literacy has developed in humans, it can wisely utilize existing energy sources not just to spend it. Major changes that can be made either producing new energy that is more environmentally friendly or wise in using energy, the most important thing in its foundation is energy literacy (Griffith, 2008). The United States has developed renewable energy in the form of solar energy and wind power generation but it has not yet run optimally due to the lack of support from the community in developing the energy, besides that the low scope of information knowledge about renewable energy developed has led to incorrect thinking about the costs must be issued (DeWaters, 2013). Not much different from Indonesia has developed solar energy, solar energy in the form of solar panels that have been used in various regions in Indonesia, but the distribution is not evenly distributed due to the lack of knowledge and the tools used to capture the sun's heat can be said to be still expensive. Efforts that can be developed to support government programs in developing renewable energy in achieving energy literacy begin at the school level both at the school and university levels.

According to Zografakis (2008) states that the ability to overcome obstacles related to energy awareness can be done on students by developing an understanding of energy literacy because this awareness can be done as early as possible so that it can continue continuously into adulthood. Later students are invited to develop energy literacy by developing abilities both cognitive, affective, and psychomotor that can be seen in the instrument. Comparative surveys conducted in Japanese areas of students who live close to nuclear power plants indicate a high level of motivation to learn about energy. They tend to have more knowledge about electricity generation and alternative energy, other than that tend to think about resources related to energy and how it would impact if energy depletion in this world. In contrast to 
students who live far from power plants tend to think more about energy in general (Fukuyama, 2008). The more students 'knowledge about energy the more will affect students' motivation towards problems regarding energy. According to Craig \& Allen (2015) an effective energy literacy program can improve the attitudes and behaviors of developing students 'energy conservation and be able to change their parents' behavior because students are able to educate parents how to use energy properly. The interaction effect that exists between teacher, student, and people and the wider community can have the effect of changing energy use behavior, especially energy savings, students are able to spread the education they get at school into their environment. The synergy effect that is intertwined is one of the important points in understanding students' energy literacy (Akitsu, 2017). Energy literacy is not only based on knowledge but includes attitudes and behaviors related to energy that can be measured. According to DeWaters (2011), mentioning the energy literacy framework includes knowledge, attitudes, and behavior. These three aspects can be measured through a questionnaire given to students to measure the ability of energy literacy known to students.

Several factors affect the level of energy literacy, one of the factors that is often discussed in research is gender. Several studies have shown that women have lower attitudes towards the role of energy or have lower levels of energy literacy compared to men based on Blasch, Djikstra, and Kumar research. But according to the research of Raty R (2010) shows that women have a higher level of energy literacy compared to men. In addition to the influence of gender factors, several studies also looked at the age of respondents, a younger person who has a level of energy literacy, especially in the use of energy in driving lower does not utilize energy as little as possible compared to older people (Kumar, 2013). The urge to develop an attitude to save energy in its utilization from childhood has a higher role to instill the habit of wise use of energy in everyday life. The role of schools is very constructive in the process of saving energy. Other factors that often arise can be the level of parental education, energy performance or role, and socioeconomic status that lead to the level of a person's energy literacy (Martins, 2019).

The purpose of this study is to determine the attitudes of junior high school students, especially in class VII who have obtained knowledge about the role of energy in the material role of energy in the life system to determine the ability of junior high school students' energy literacy in aspects of saving energy, renewable energy, and the role of energy reviewed from students' attitudes and behavior in daily life. The results of the study are based on the results of an online questionnaire survey by looking at conditions that were happening during the pandemic. The use of instruments adapts from DeWaters (2013) research with various adjustments to the area to be used.

\section{RESEARCH METHODS}

This research uses descriptive online research design. Descriptive design is used to describe students' attitudes about the role of energy in living systems that are implemented from everyday life. The study was conducted online in May 2020. The population of this study was junior high school students in Central Java, especially the Surakarta and Banjarnegara residency areas. The sampling technique used issimple random sampling, sampling is done randomly without regard to the special characteristics of students. The sample of this study was 183 junior high school students who were in the Surakarta and Banjarnegara residencies consisting of 61 male students and 122 female students. 
This research was conducted by providing an instrument or framework of energy literacy on the subject of the role of energy in life in the form of an online questionnaire to the sample. The instrument was compiled by researchers based on a framework that was created by DeWaters (2013) by modifying the contents adapted to the environment in Indonesia and the transfer of languages to Indonesian. Based on a literature review on energy literacy, the aspects that are observed include aspects of knowledge, attitudes, and behavior. In this study in accordance with its purpose, namely to use two aspects of attitude and behavior. From the aspect of attitude and behavior are broken down into 30 question items which are divided into 3 sub-topics or aspects namely saving energy, renewable energy, and the role of energy.energy saving statements, 9 renewable energy statement items, and 6 energy role statement items.

From these statements respinden asked to choose responses that are in accordance with his understanding or that are considered in accordance with the circumstances of the respondent. There are five responses that can be chosen consisting of (1) strongly disagree, (2) disagree, (3) sometimes, (4) agree, (5) strongly agree. Analysis of the statements of respondents taken through a questionnaire was carried out in several stages. First the results of the questionnaire are grouped by each aspect and processed using Microsoft Excel. The second analysis is to use the SPSS version 24 non-parametric test programChi square to find out the relationship of the three aspects and whether gender influences students' attitudes and behavior towards the role of energy in living systems.

\section{RESULTS AND DISCUSSION}

The study was carried out in stages at each school by spreading online questionnaire links assisted by teachers to disseminate to their students. Students respond to the survey statement in the form of a google form distributed to a number of junior high schools in Central Java to reduce socialization following the government's suggestion to reduce the crowd during the pandemic. The results of student responses are then processed or transferred in a Microsoft Excel worksheet to be analyzed. Item responses are converted to numeric assessments according to subscales that have been determined on the linkert scale. The scale used from 1 in the strongly disagree choice to scale 5 in the form of a strongly agree choice, the blank response in this scale is removed from the analysis. Responses from the three aspects were analyzed separately then seen the relationship of each aspect of what affects or not and viewed from the influence of gender as well. The instrument follows the energy literacy framework created by DeWaters (2013) by modifying it according to the students' environmental conditions. From the results of the next student survey the results obtained using calculations on SPSS version 24 on all three aspects.

Table 1. Average results of students' attitudes and behavior on all three aspects of energy

\begin{tabular}{|c|c|c|c|}
\hline Scale & $\begin{array}{c}\text { The energy saving } \\
\text { aspect }\end{array}$ & $\begin{array}{c}\text { Renewable energy } \\
\text { aspects }\end{array}$ & $\begin{array}{c}\text { The role aspect of } \\
\text { energy }\end{array}$ \\
\hline Item & 15 & 9 & 6 \\
\hline Median & 58 & 34 & 18 \\
\hline The mean & 60.24 & 34,15 & 19.35 \\
\hline Elementary school & 11,303 & 7,668 & 5,379 \\
\hline
\end{tabular}

In this study did not take a cognitive assessment so that the level of item difficulty which is raised but rather looks at students' attitudes and behavior on all three aspects. In 
nonparametric calculations using Chi Square to see the relationship between the three aspects and gender.

Table 2. Chi Square calculation results

\begin{tabular}{|c|c|c|c|}
\hline Scale & $\begin{array}{c}\text { The energy saving } \\
\text { aspect }\end{array}$ & $\begin{array}{c}\text { Renewable energy } \\
\text { aspects }\end{array}$ & $\begin{array}{c}\text { The role aspect of } \\
\text { energy }\end{array}$ \\
\hline Gender & 0.260 & .643 & .694 \\
\hline $\begin{array}{c}\text { The energy saving } \\
\text { aspect }\end{array}$ & - & 0.002 & 0.004 \\
\hline $\begin{array}{c}\text { Renewable energy } \\
\text { aspects }\end{array}$ & 0.002 & - & 0,000 \\
\hline $\begin{array}{c}\text { The role aspect of } \\
\text { energy }\end{array}$ & 0.004 & 0,000 & - \\
\hline
\end{tabular}

That gender does not have a significant influence on students' attitudes and behavior regarding the conception of the role of energy based on the energy literacy framework. Whereas several studies show that the influence of sex on the level of energy literacy, according to Blasch et al (2018) that the level of energy literacy in women is lower than men while according to Raty (2010) shows the results that are inversely proportional that women have a literacy level higher energy compared to men. However, if seen from the relationship of the three aspects show a significant relationship so that aspects that affect each other, such as the aspect of saving energy with renewable energy shows the results $0.002<0,05$ so that there is a relationship between aspects of saving energy and renewable energy. As in the aspect of the role of energy also shows the relationship on aspects of saving energy and aspects of renewable energy.

In some aspects the students' responses showed a negative attitude such as saving the use of lights during the daytime some students were still being indifferent to this attitude, but there were also some students who were aware that when the day was sunny it could turn off the light source as an energy saving measure. In addition, some students encourage the use of renewable energy activities such as solar energy and water as a source of companion energy from fossils, but some students respond to disagreement on the grounds that they do not know whetherthe benefits of renewable energy. This is consistent with the research developed by DeWaters et al (2011) that as many as one-third of students were observed to know that energy conservation is appropriate for their needs and that most students are able to save energy. Of course the application of the role of energy in living systems is influenced by learning taught at school through energy material in living systems. Assistance from understanding provided by schools can improve students' attitudes to care for the environment, one of which is by saving energy. This is supported by Nordine (2010) that the basic concept of energy saving can be developed by students into a superior understanding through learning from school.

\section{CONCLUSION}

Students' attitudes and behavior are related from all three aspects of saving energy, renewable energy, and the role of energy. Seen from the results of the Chi square analysis showed a significant relationship between the three aspects. However, if viewed from the relationship of sex and the three aspects there is no significant relationship so that gender does not affect the level of energy literacy of students. The level of understanding of the attitudes and behavior of students in energy savings there are still some students who show negative attitudes. This can be supported by developing understanding of concepts that exist in schools, 
can improve students' attitudes and behavior towards energy savings and increase understanding of the use of renewable energy as a companion to fossil energy.

\section{BIBLIOGRAPHY}

Akitsu, Y., Ishihara, K. N., Okumura, H., Yamasue, E. (2017). Investigating energy literacy and its structural model for lower secondary students in Japan. International Journal of Environmental \& Science Education, 12(5), 1067-1095.

Barrow,L. H., \& Morrisey, J. T. (1989). Energy literacy of ninth-grade students: A comparison between Maine and New Brunswick. Journal of Environmental Education, 20(2), 22-25.

Blasch J, Boogen N, Daminato C, Filippini M. (2018). Empower the Consumer! EnergyRelated financial literacy and its socioeconomic determinants, 18/289.

Brounen D, Kok N, Quigley JM. (2013). Energy literacy, awareness, and conservation behavior of residential households. Energy Econ,38. 42-50.

Craig, C., \& Allen, M. W. (2015). The impact of curriculum based learning on environmentak literacy and energy consumption with implication for policy. Uttilities policy, 36, 41-49.

DeWaters JE, Powers SE. (2011). Energy literacy of secondary students in New York State (USA): A measure of knowledge, affect, and behavior. Energy Policy, 39(3). 1699-710.

DeWaters, Jan. 2013. Designing an Energy Literacy Questionnaire for Middle and High School Youth. Journal of Environmental Education, 44(1), 56-78.

Dijkstra EM, Goedhart MJ. (2012). Development and validation of the ACSI: measuring students' science attitudes, pro environmental behaviour, climate change attitudes and knowledge. Environ Educ Res, 18(6). 733-749.

Energy Literacy Advocates. (2009). Energy Literacy Advocates. Retrieved from www.energyliteracy.org.

Fukuyama, T. (2008). Baseline survey on junior high school students knowledge and interest concerning energy in Ehime prefecture. The Bulletin of the Faculty of Educaton Ehime Univesity, 55(1), 146-161.

Griffith, S. (2008). Energy literascy. From O'Reilly Emerging Tchnology Conference, San Diego, CA.

Kalmi P, Trotta G, Kazukauskas A. (2017). The role of energy literacy as a component of financial literacy: Survey-based evidence from Finland. In: IAEE conference in Vienna.

Kementrian Energi dan Sumber Daya Mineral. (2016). Program Strategis EBTKE dan Ketenagalistrikan. Jurnal Energi, 2, 1-100.

Kumar N. (2019). A model-based clustering approach for analyzing energy-related financial literacy and its determinants. CER-ETH-Center of Economic Research at ETH Zurich, 19,312 . 
Martins, A., Madaleno, M., \& Dias, M.F. (2019). Energy literacy: What is out there to know?. Energy Reports, 6:2020. 454-459.

Raty R, Carlsson-Kanyama A. (2010). Energy consumption by gender in some European countries. Energy Policy,38(1). 646-654.

USDepartment of Energy. (2017). U.S. Department of Energy, Energy Literacy: Essencial principles and fundamental concepts for Energy Education.

Zografakis, N., Menegaki, A. N., \& Tsagarakis, K. P. (2008). Effective education for energy efficiency. Energy Policy, 36, 3226-3232. 


\section{ATTACHMENT}

\section{STATEMENT OF AN ATTITUDE AND BEHAVIOR}

\section{ASPECT OF ENERGY SAVING}

1. I save on daily use

2. When I left the room, I turned off the light.

3. I use or turn on the lights during the daytime.

4. When going somewhere with short distances I walk not drive.

5. My family turns off the electronics when nighttime is not needed.

6. I don't use excessive electronic devices, when nothing important is done.

7. I don't have to worry about turning on the lights and air-conditioning in the classroom, when it's not needed because the school pays for electricity and I contribute to paying tuition fees.

8. I would be more willing to save energy if I knew how.

9. I give advice to families on how to save energy.

10. I believe that I can participate in solving problems related to energy by participating in saving energy as needed.

11. Indonesian citizens must save a lot of energy.

12. I am willing to buy electronic goods that are only needed in order to save energy.

13. All electrical equipment must have information showing the resources used by the energy expended.

14. My family uses energy saving lamps.

15. Saving energy is very important.

\section{RENEWABLE ENERGY ASPECTS}

1. The way I use energy sees no boundaries, even though many problems regarding energy that are running low are being faced by our nation.

2. Better to use a lot of solar power as electricity generation, because the sun's heat will not run out.

3. Laws regarding the protection of the natural environment must be made loose to allow more energy to be produced.

4. Efforts to develop renewable technologies such as solar power and hydropower are more important than efforts to develop fossil fuels that are running low.

5. Indonesia must develop more ways to use renewable energy such as solar, water and wind.

6. We have to make more power from renewable energy sources.

7. The government must tighten the use of energy resources by cooperating with the people.

8. We don't need to worry about preserving or saving energy because new technologies will be developed to solve problems related to the availability of energy for future generations.

9. Education about energy, including types of renewable energy such as solar, water, and wind, is important in learning. 


\section{ENERGY ROLE ASPECT}

1. I leave plants dead just like that, but I don't treat them, even though I know plants can provide energy.

2. I always eat balanced foods such as carbohydrates, protein, and fat to increase energy in the body.

3. Families like to eat sweet foods and rarely exercise.

4. When I made observations related to photosynthesis, stated that plants produce oxygen which is used as a source of human energy.

5. At night you cannot sit under a tree because plants emit carbon dioxide.

6. During the process of photosynthesis there are plants that do not need light as an energy source. 